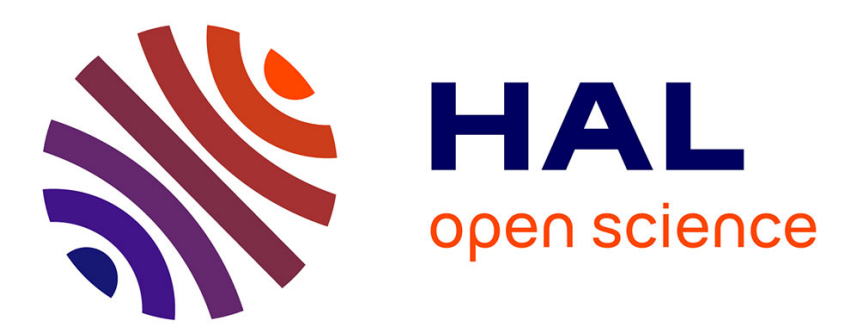

\title{
Seasonal availability of floral resources and ambient temperature shape stingless bee foraging behavior (Scaptotrigona aff. depilis)
}

Kátia Paula Aleixo, Cristiano Menezes, Vera Lúcia Imperatriz Fonseca, Cláudia Inês da Silva

\section{To cite this version:}

Kátia Paula Aleixo, Cristiano Menezes, Vera Lúcia Imperatriz Fonseca, Cláudia Inês da Silva. Seasonal availability of floral resources and ambient temperature shape stingless bee foraging behavior (Scaptotrigona aff. depilis). Apidologie, 2017, 48 (1), pp.117-127. 10.1007/s13592-016-0456-4 . hal-01541224

\section{HAL Id: hal-01541224 \\ https://hal.science/hal-01541224}

Submitted on 18 Jun 2017

HAL is a multi-disciplinary open access archive for the deposit and dissemination of scientific research documents, whether they are published or not. The documents may come from teaching and research institutions in France or abroad, or from public or private research centers.
L'archive ouverte pluridisciplinaire HAL, est destinée au dépôt et à la diffusion de documents scientifiques de niveau recherche, publiés ou non, émanant des établissements d'enseignement et de recherche français ou étrangers, des laboratoires publics ou privés. 


\title{
Seasonal availability of floral resources and ambient temperature shape stingless bee foraging behavior (Scaptotrigona aff. depilis)
}

\author{
Kátia Paula Aleixo ${ }^{1}$, Cristiano Menezes ${ }^{2}$, Vera Lúcia ImPeratriz Fonseca ${ }^{1,3}$, \\ Cláudia Inês da SILva ${ }^{1,4}$ \\ ${ }^{1}$ Departamento de Biologia, Faculdade de Filosofia, Ciências e Letras de Ribeirão Preto (FFCLRP), Universidade de São \\ Paulo, Avenida Bandeirantes, 3900, Bairro Monte Alegre, CEP 14040-901, Ribeirão Preto, São Paulo, Brazil \\ ${ }^{2}$ Embrapa Amazônia Oriental, Travessa Dr. Enéas Pinheiro s/n, C.P. 48, CEP 66095-100, Belém, Pará, Brazil \\ ${ }^{3}$ Instituto Tecnológico Vale, Rua Boaventura da Silva, 955, CEP 66055-090, Belém, Pará, Brazil \\ ${ }^{4}$ Instituto de Biociências, Universidade de São Paulo, Rua do Matão, Travessa 14, Butantã, CEP 05508-090, São Paulo, \\ São Paulo, Brazil
}

Received 11 November 2015 - Revised 30 May 2016 - Accepted 3 June 2016

\begin{abstract}
The foraging success of a bee species is related to a combination of climatic factors and resource availability. Here, we analyzed how food storage by the stingless bee Scaptotrigona aff. depilis relates to the seasonal variation in floral resources availability in a tropical environment with two well-defined seasons. We found a positive relationship between the amount of food stored and resource availability, suggesting that colonies intensify food collection in the season with higher food availability (rainy season). This ensures the perennial state of stingless bee colonies during the dry season (food scarcity and lower ambient temperatures). Bees collected pollen from at least 60 plant species, but food pots were dominated by just nine plants. Additionally, $S$. aff depilis attempted to unevenly use the plant species for food storage in the rainy season, which indicates that the colonies maximize their food intake as soon as resources are available.
\end{abstract}

\section{diet / generalist / native bees / pollen analysis / tropical region}

\section{INTRODUCTION}

In tropical environments the most abundant flower visitors are bees, of which many belong to eusocial species within the family Apidae (stingless bees, bumblebees, and honeybees) (Roubik 1989). In contrast to solitary insects, which collect food for their individual and offspring's survival, foragers of social insect colonies collect food to ensure the

Electronic supplementary material The online version of this article (doi:10.1007/s13592-016-0456-4) contains supplementary material, which is available to authorized users.

Corresponding author: K. Aleixo, katialeixo@yahoo.com.br Manuscript Editor: James Nieh successful rearing of the brood and to satisfy the energetic demands of all non-foraging adults. Therefore, the survival of a bee colony depends upon the success of the workers in collecting nectar, a source of carbohydrates, and pollen, a source of proteins and vitamins, from flowers (Michener 2007).

In Neotropical regions, eusocial bees forage continuously, with workers collecting pollen and nectar from an array of plant species throughout the year (Roubik 1989; Ramalho et al. 1990). However, they can intensify resource collection from certain species for an amount of time, as shown previously for bumblebees (Camillo and Garofalo 1989), honeybees (Ramalho et al. 1990; Wilms et al. 1996), and stingless bees (Ramalho et al. 1990, Vossler et al. 2010; Aleixo et al. 2013; Maia-Silva et al. 2014). 
In stingless bee colonies, food collection is influenced by both abiotic factors, such as temperature and rainfall (Hilário et al. 2001; Kajobe and Echazarreta 2005; Teixeira and Campos 2005; Figueiredo-Mecca et al. 2013), and differences in floral resource availability (e.g., pollen and nectar) between natural and altered landscapes (forest, gardens and agricultural plantations) (Kaluza et al. 2016). Roubik (1982) showed that the amount of pollen and honey stored in colonies of Melipona stingless bees varied greatly across time and concluded that flowering seasonality influenced the foraging activity of bees. For example, in periods of low pollen availability, foraging for this resource declined markedly in the bee Melipona beecheii (Biesmeijer et al. 1999). Although Roubik (1982) and Biesmeijer et al. (1999) observed the use of such strategies by bees according to the temporal variation in food availability, flowering phenology was not assessed in these studies.

Smith et al. (2012) conducted the first community-level study of the relationship between the spatiotemporal distribution of pollen resources and bee foraging behavior in a diverse tropical lowland forest. The authors studied the foraging behavior of the generalist bees of genus Megalopta (Halictidae), and showed that they used more than 64 species of pollen, but relied heavily on just a few species. For stingless bees, Eltz et al. (2001), Faria et al. (2012), and Aleixo et al. (2013) are some of the few studies to quantify natural resource availability and to analyze the effects of flowering seasonality on the selection of food sources by bees. These studies indicated that in periods of greater floral source availability the workers collected proportionately fewer pollen types, focusing on those plants that offer more profitable resources.

Here we present the first community-level study of the relationship between the spatiotemporal distribution of floral resources and colony food storage in a tropical area using the generalist stingless bee, Scaptotrigona aff. depilis. The lack of feasible methods for the assessment of resource storage in stingless bee colonies and the difficulty in analyzing the flowering phenology in tropical plant communities contribute to this gap in knowledge.
The method developed by Menezes et al. (2012), used in the present study, allowed the assessment of not only food intake but also the quantification of this resource in stingless bee colonies. Thereafter, we analyzed how food storage by $S$. aff. depilis relates to the seasonal variation in floral resources availability in a tropical environment with two well-defined seasons. We hypothesized that foragers would intensify food storage in the season with higher food availability and higher temperatures, probably to optimize the maintenance and survival of the colony in periods of food scarcity.

\section{MATERIAL AND METHODS}

\subsection{Study site}

We carried out the study from April 2011 to March 2012 at the Universidade de São Paulo ( $21^{\circ} 9.4^{\prime} \mathrm{S}, 47^{\circ} 51.3^{\prime} \mathrm{W}$; Ribeirão Preto, SP, Brazil). The vegetation of the campus is composed of 75 ha of areas reforested with native species (Pais and Varanda 2010), and gardens with native and exotic plants used in urban landscaping. The climate of the Ribeirão Preto region is characterized by two welldefined seasons; a dry, cold season extending from April to September and a wet, warm season from October to March (Figure 1).

\subsection{Floristic composition, flowering phenology and floral resource availability}

The floristic composition was studied in an area with a radius of $500 \mathrm{~m}$, amounting to $78 \mathrm{ha}$, once a month. The center of this area was the bee-rearing facilities of FFCLRP, where nests of $S$. aff. depilis were located. Each plant species was classified according to their main floral resource available for bees: pollen, nectar or floral oil (for full species list see Electronic supplementary material, Table I). The flowering phenology was studied concomitantly to plant inventory by recording the number of individuals per species in blossom. Then, we used the number of individuals providing pollen and nectar to estimate the availability of these floral resources throughout the year. 


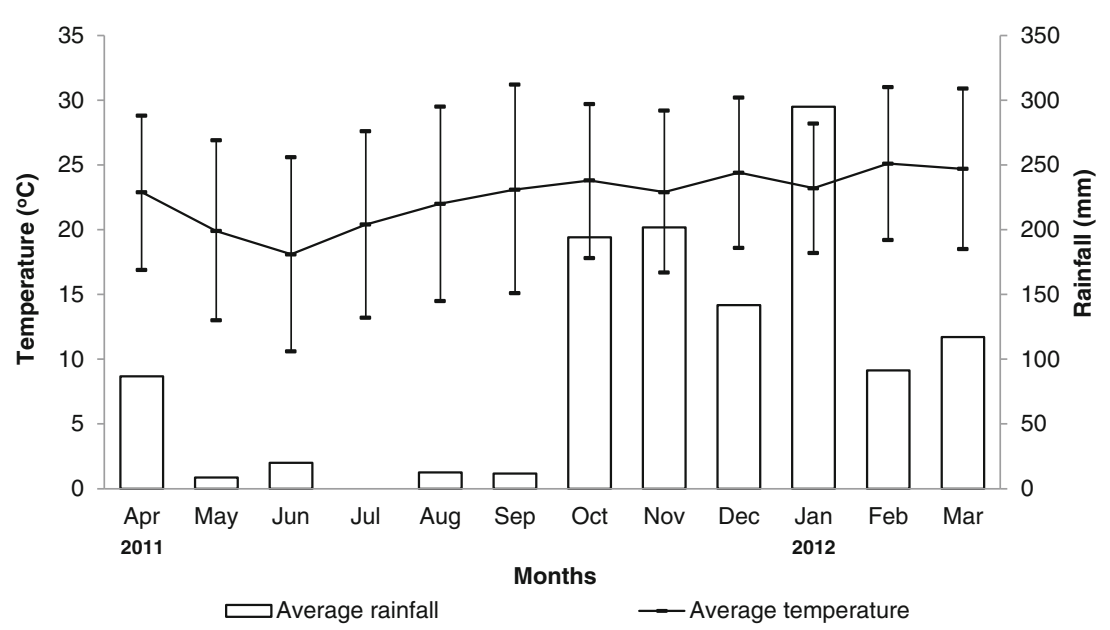

Figure 1. Distribution of average monthly, average monthly maximum, and average monthly minimum temperatures $\left({ }^{\circ} \mathrm{C}\right)$ and of rainfall $(\mathrm{mm})$ in Ribeirão Preto between April 2011 and March 2012.

\subsection{Stored food and identification of floral sources}

The collection of food stored by foragers followed Menezes et al. (2012). The method consisted of changing the location of a colony (mother colony $[\mathrm{MC}]$ ) and replacing it with an empty wooden box (experimental box [EB]), which was occupied by the returning foragers and used for storing pollen and nectar. Initially, the EBs had two pots of wax and a wax blade to help the bees to construct new food pots, involucres and entrance tubes.

We selected eight MCs for the formation of EBs. We divided the MCs into two groups of four colonies and used only one group each month to reduce the negative impacts of manipulation in subsequent studies. Therefore, we used four colonies in April, June, August, October, December, and February, and the other four colonies in May, July, September, November, January, and March. Each EB remained in the field for 7 days. After this period, the following characteristics were analyzed for each EB: (1) the number of pots with pollen and honey built and stored; (2) the pollen mass $(\mathrm{g})$ and honey volume $(\mathrm{mL})$ stored in the pots; (3) the number of pollen types in the pots with pollen; (4) the relative frequency $(\%)$ of pollen types in the pots with pollen.

We removed the pollen stored in the pots of each colony, put it in a Petri dish for homogenization, and measured the pollen mass on a high-precision scale. We collected the honey with a Pasteur pipette and measured its volume in graduated plastic tubes. We identified the floral sources used by the bees through an analysis of the pollen grains sampled from the pots with pollen. Samples collected from each Petri dish were acetolized according to Erdtman (1960), and the floral origin of the pollen was identified by comparison with reference collection at FFCLRP.

\subsection{Data analysis}

To test for seasonality in the availability of floral resources, we used the Rayleigh test of uniformity $(Z)$ for circular distributions (Zar 1999). The Rayleigh test determines the significance of the average date (in months; $P<0.05$ ). The hypotheses tested were: $\mathrm{H}_{0}=$ the average date is not significant, plant individuals providing floral resources are uniformly distributed throughout the year, and, therefore, there is no seasonality; $\mathrm{H}_{1}=$ the average date is significant, the highest frequency of plant individuals providing floral resources is distributed around the average date, and, therefore, there is some seasonality. If $\mathrm{H}_{1}$ is accepted, the degree of seasonality in resource availability is denoted by vector $r$, which shows the intensity of concentration around the average date. The value of $r$ ranges from 0 (when there is so much dispersion that an average date cannot be described) to 1 (when all the data are concentrated at the same direction). The analysis was performed in the Oriana software (Kovach 2012). 
To study the foraging activity, we performed the analysis considering month-pair, totaling three monthpairs for each season. The following month-pairs were considered: April-May, June-July, August-September, October-November, December-January, and February-March. Eight EBs were studied during each month-pair.

We used linear mixed-effects models (LMEs) to test the effect of floral resource availability and climatic factors on pollen mass and honey volume stored in the food pots of the EBs (R Development Core Team 2011; library nlme: Pinheiro et al. 2015). We chose this approach because these models control the dependence among the data obtained from each of the eight colonies, by including 'colony' as a random component. The fixed component of the LMEs was the explanatory variables: pollen and nectar availability, represented by the number of individuals in blossom during the study period, and the climatic factors, represented by the monthly average temperature and rainfall. To select the best models we followed the protocol proposed by Zuur et al. (2009) (for details, see Electronic supplementary material).

A simple linear regression between the amount of food stored (pollen and honey) in EBs and resource availability (pollen and nectar, respectively) was used to test if foragers intensified food storage in the season with higher food availability.

For the quantitative analysis of the pollen found on the slides, we counted the first 400 pollen grains, as in Montero and Tormo (1990). Next, we determined the frequency classes proposed by Louveaux et al. (1978): predominant pollen ( $>45 \%$ of the total of pollen grains on the slide), secondary (15-44\%), important minor (3$14 \%)$ and minor $(<3 \%)$. For each season, considering monthly percentages of pollen grains, plant species with predominant pollen were considered food sources that were intensively exploited by bees.

To compare the diversity of food sources used by bees between dry and rainy seasons, we used the Shannon index of diversity (Shannon and Weaver 1949): $H^{\prime}$ $=-\sum\left(p_{h} \times \ln p_{h}\right)$, where $p_{h}$ is the proportion of each pollen type in the total sample. The Shannon index of diversity for each season was calculated considering all pollen types used and the sum of their frequencies of pollen grains from April to September (dry season) and from October to March (rainy season). To test for a difference between the two diversity indices the $t$-test proposed by Hutcheson (1970) was used (Zar 1999).
We also calculated the evenness index according to Pielou (1966): $J^{\prime}=\mathrm{H}^{\prime} / \mathrm{H}_{\max }$, where $\mathrm{H}^{\prime}$ is the Shannon index of diversity and $\mathrm{H}_{\max }$ the logarithm (ln) of the total number of pollen types used by bees. This index varies from 0 (irregular utilization of the different food sources) to 1 (uniform utilization of the different food sources). The same approach was used to compare the diversity of available sources between dry and rainy seasons, where $\mathrm{p}_{\mathrm{h}}$ is the proportion of each plant species that bloomed in the study area.

To test for a correlation between available and used diversity, the Shannon index of diversity was calculated for each month (Electronic supplementary material, Table III). We used the PAST software (Hammer et al. 2001) to perform the diversity analysis.

\section{RESULTS}

The dry season was colder $\left(21 \pm 1.95{ }^{\circ} \mathrm{C}\right)$ and driest $(23.3 \pm 31.77 \mathrm{~mm})$ than the following months (rainy season: $24 \pm 0.86{ }^{\circ} \mathrm{C} ; 173.5 \pm$ $73.37 \mathrm{~mm}$ ). June-July was the coldest month-pair, while February-March was the hottest one (Figure 1). In the course of this study, we identified 289 plant species in blossom (for full species list see Electronic supplementary material, Table I). A total of 244 plant species were sampled in the dry season, and a total of 226 species were sampled in the rainy season.

Food availability for bees was continuous throughout the year (Figure 2). The period with the highest number of individuals that provided pollen occurred in the rainy season (DecemberMarch). Pollen availability was seasonal and the highest frequency of plant individuals that provided pollen was distributed around February $(Z=$ 396.49; $P<0.01$ ) (Figure 2a). The period with the highest number of individuals that provided nectar occurred in the rainy season and also in the beginning of the dry season (January-May). Nectar availability was also seasonal and the highest frequency of individuals that provided nectar was distributed around April $(Z=57.40$; $P<0.01$ ) (Figure 2b). However, the seasonality for pollen availability was stronger than the seasonality for nectar availability $\left(r_{\text {pollen }}=0.20>\right.$ $\left.r_{\text {nectar }}=0.07\right)$, which shows that pollen availability was clustered more closely around February, whereas plant individuals that provided nectar 

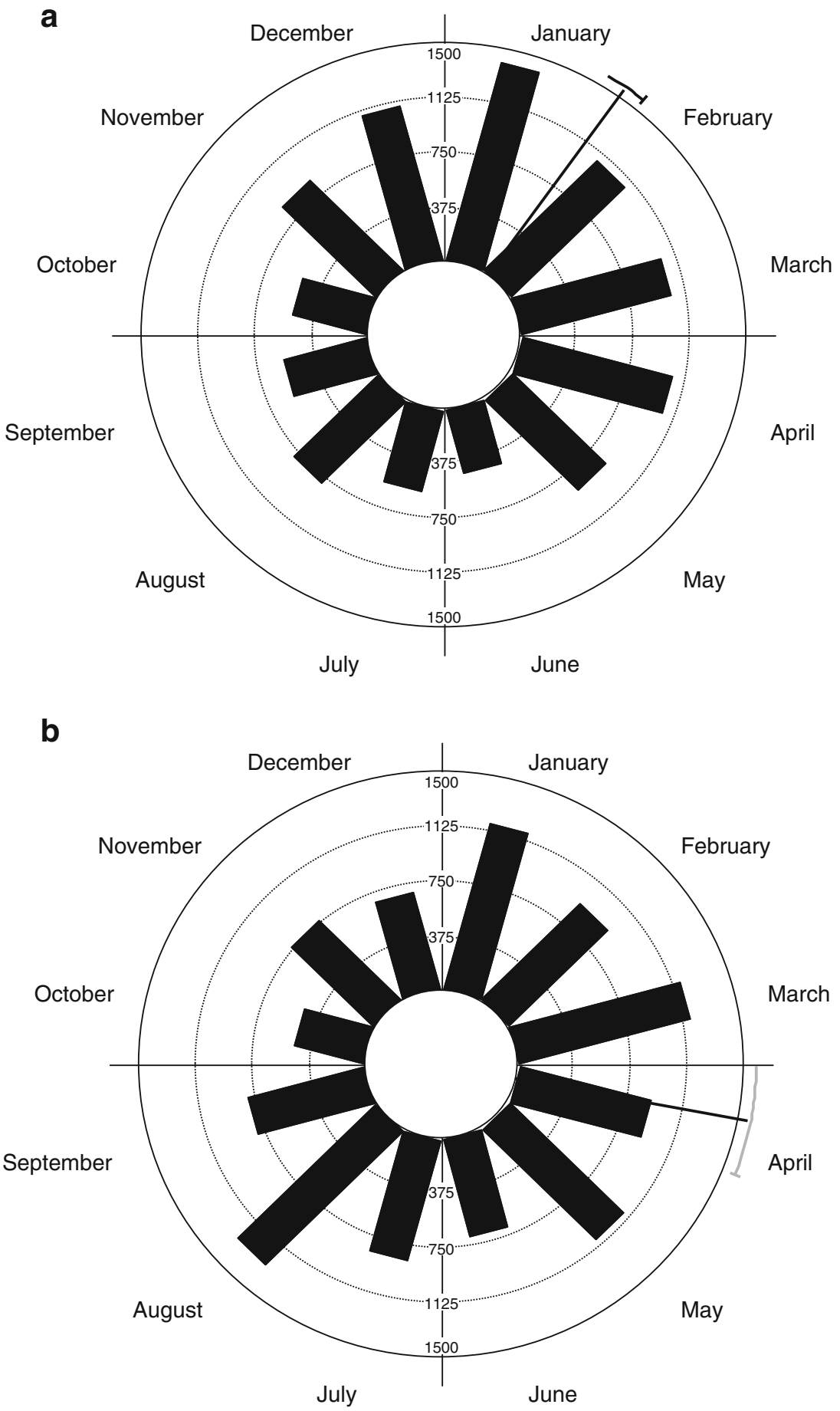

Figure 2. Circular distribution of floral resources available to bees, represented by the number of individual plants in blossom from April 2011 to March 2012 at the campus of USP-RP. a Pollen availability. b Nectar availability. In the histogram, the vector indicates the average date of occurrence of the event. The histogram bars indicate the number of individuals that bloomed in each month. The line at the top of the vector represents the confidence limit of the average date, i.e., $95 \%$ confidence limit. 
were more evenly distributed throughout the year (Figure 2b).

Pollen storage increased with pollen availability $\left(r_{s}=0.61 ; P<0.001\right)$, temperature $\left(r_{s}=0.54\right.$; $P<0.001)$ and rainfall $\left(r_{s}=0.36 ; P<0.05\right)$, but it was not affected by nectar availability $\left(r_{s}=\right.$ $0.14 ; P>0.05)$. Differences in the amount of pollen stored throughout the year were best explained by pollen availability (LME test: $F_{1.31}=$ 12.09; $P<0.001)$. Across seasons, a larger amount of pollen was stored during the rainy season, with a peak of storage in February-March (Table I).

Honey storage also increased with pollen availability $\left(r_{s}=0.53 ; P<0.001\right)$, nectar availability $\left(r_{s}=0.44 ; P<0.01\right)$, temperature $\left(r_{s}=0.63\right.$; $P<0.001)$ and rainfall $\left(r_{s}=0.36 ; P<0.05\right)$. Differences in honey volume stored throughout the year were best explained by the interaction between nectar availability and temperature (Table II). That is to say, honey storage in EBs differed between temperatures of seasons for different nectar availability. For instance, honey began to be stored at the end of the colder dry season and was stored throughout the rainy season, with a peak of storage also in FebruaryMarch (Table I).

Pollen availability positively explained the variation in the amount of pollen stored throughout the year $\left(\beta=7.58 ; r^{2}=0.21 ; P<0.01\right)$. A positive relation was also found between the volume of honey stored and nectar availability $(\beta=8.11$; $\left.r^{2}=0.12 ; P<0.05\right)$.

Foraging bees of $S$. aff. depilis used 66 pollen types from 30 families and 54 genera of plants to supply the pollen pots, showing that the workers collected floral resources from a small fraction of the total number of plant species available $(\sim 23 \%$ of the species that bloomed from April 2011 to March 2012). Of these 66 pollen types, 60 were identified at species level. Trees were broadly exploited and represented $68 \%$ of the plants used by the bees (Electronic supplementary material, Table IV).

In the dry season, bees used 43 pollen types, which corresponded to $18 \%$ of the total number

Table I. Food stored in the experimental colonies ( $n=8$ colonies per month-pair), from April 2011 to March 2012.

\begin{tabular}{|c|c|c|c|c|c|c|}
\hline & \multicolumn{3}{|l|}{ Dry season } & \multicolumn{3}{|c|}{ Rainy season } \\
\hline & Apr-May ${ }^{\mathrm{a}}$ & ${\text { Jun}-J u l^{\mathrm{a}}}$ & Aug-Sep & Oct-Nov & Dec-Jan & Feb-Mar \\
\hline \multicolumn{7}{|c|}{ Pots with pollen } \\
\hline Total & 16 & 12 & 24 & 14 & 55 & 49 \\
\hline $\begin{array}{l}\text { Mean } \pm \text { SD } \\
(\min -\max )\end{array}$ & $\begin{array}{l}2.00 \pm 1.20 \\
(0-4)\end{array}$ & $\begin{array}{l}1.50 \pm 1.07 \\
(0-3)\end{array}$ & $\begin{array}{l}3.00 \pm 1.51 \\
(1-5)\end{array}$ & $\begin{array}{l}1.75 \pm 2.38 \\
(0-7)\end{array}$ & $\begin{array}{l}6.88 \pm 5.87 \\
(2-19)\end{array}$ & $\begin{array}{l}6.13 \pm 4.12 \\
(2-12)\end{array}$ \\
\hline \multicolumn{7}{|l|}{ Pollen mass (g) } \\
\hline Total & 53.38 & 36.92 & 59.94 & 11.82 & 225.14 & 242.28 \\
\hline $\begin{array}{l}\text { Mean } \pm \text { SD } \\
(\text { min-max })\end{array}$ & $\begin{array}{l}6.67 \pm 6.18 \\
(0-17.22)\end{array}$ & $\begin{array}{l}4.62 \pm 4.01 \\
(0-11.47)\end{array}$ & $\begin{array}{l}7.49 \pm 6.74 \\
(0.19-21.79)\end{array}$ & $\begin{array}{l}1.48 \pm 1.63 \\
(0-3.72)\end{array}$ & $\begin{array}{l}28.14 \pm 17.10 \\
(0.32-56.82)\end{array}$ & $\begin{array}{l}30.29 \pm 24.23 \\
(9.58-81.38)\end{array}$ \\
\hline \multicolumn{7}{|c|}{ Pots with honey } \\
\hline Total & & & 9 & 1 & 23 & 38 \\
\hline $\begin{array}{l}\text { Mean } \pm \text { SD } \\
\text { (min-max) }\end{array}$ & & & $\begin{array}{l}1.13 \pm 0.99 \\
(0-2)\end{array}$ & $\begin{array}{l}0.13 \pm 0.35 \\
(0-1)\end{array}$ & $\begin{array}{l}2.88 \pm 3.31 \\
(0-10)\end{array}$ & $\begin{array}{l}4.75 \pm 2.43 \\
(0-8)\end{array}$ \\
\hline \multicolumn{7}{|c|}{ Honey volume (mL) } \\
\hline Total & & & 12.00 & 0.20 & 49.00 & 161.00 \\
\hline $\begin{array}{l}\text { Mean } \pm \text { SD } \\
\text { (min-max) }\end{array}$ & & & $\begin{array}{l}1.50 \pm 1.44 \\
(0-3.50)\end{array}$ & $\begin{array}{l}0.03 \pm 0.07 \\
(0-0.20)\end{array}$ & $\begin{array}{l}6.13 \pm 6.71 \\
(0-17.00)\end{array}$ & $\begin{array}{l}20.13 \pm 13.50 \\
(0-41.50)\end{array}$ \\
\hline
\end{tabular}

${ }^{\mathrm{a}}$ There was no storage of honey in these months 
Table II. Statistical results of linear mixed-effects models (LMEs) analyzing the effect of nectar availability, ambient temperature and their interactions on the differences in the honey volume stored in the experimental colonies from April 2011 to March 2012.

\begin{tabular}{llll}
\hline & \multicolumn{3}{l}{ Honey volume } \\
\cline { 2 - 4 } & DF & \multicolumn{1}{c}{ F } & \multicolumn{1}{l}{$P$} \\
\hline Nectar availability & 29 & 9.52 & $<0.01$ \\
Temperature & 29 & 16.28 & $<0.001$ \\
Interaction & 29 & 17.53 & $<0.001$ \\
\hline
\end{tabular}

of plant species available in this season. Considering monthly storage, the species Eucalyptus moluccana, E. grandis, and Myracrodruon urundeuva were intensively exploited to supply the pollen pots. The pollen grains of these three plant species counted in the slides corresponded to $45 \%$ of all pollen grains in the dry season (Electronic supplementary material, Table IV). In the rainy season, bees used 40 pollen types, which also corresponded to $18 \%$ of the total number of plant species available in this season. Considering monthly storage, only Schinus terebinthifolius was an intensively used source in February, but this species represented only $23 \%$ of all pollen grains used in the rainy season. Around $64 \%$ of all pollen grains used to supply the pollen pots in the rainy season were collected in the species classified as secondary pollen: E. moluccana, Eugenia uniflora, Mimosa caesalpiniifolia, Muntingia calabura, Punica granatum, and Serjania lethalis .

There was no correlation between available and used diversity $(r=0.003 ; P>0.05)$. Therefore, the diversity of sources used to food storage did not depend on diversity of available sources in the study area. Diversity of available sources declined from the dry to the rainy season $\left(H^{\prime}{ }_{d r y}\right.$ season $=4.01, H$ 'rainy season $=3.79 ; t=3.86, P<0.001)$, as well as the evenness $\left(J^{\prime}{ }_{\text {dry season }}=0.73, J^{\prime}\right.$ rainy season $=$ $0.70)$. Diversity of pollen types used per season also declined from the dry to rainy season $\left(H^{\prime}\right.$ dry season $=$ $4.01, H^{\prime}$ rainy season $\left.=3.79 ; t=3,86, P<0.001\right)$ as well as the evenness $\left(J^{\prime}\right.$ dry season $=0.69, J^{\prime}$ rainy season $=0.61$ ), indicating that the plant species were used more evenly in the dry season (Figure 3).

\section{DISCUSSION}

The present study showed that seasonal availability of floral resources and ambient temperature shape $S$. aff. depilis foraging behavior. Pollen storage was continuous across seasons and increased with higher pollen availability. Despite the continuous availability of nectar, honey began to be stored at the end of the dry season, when ambient temperature began to rise. The bees used $\geq 60$ plant species for food storage, suggesting that

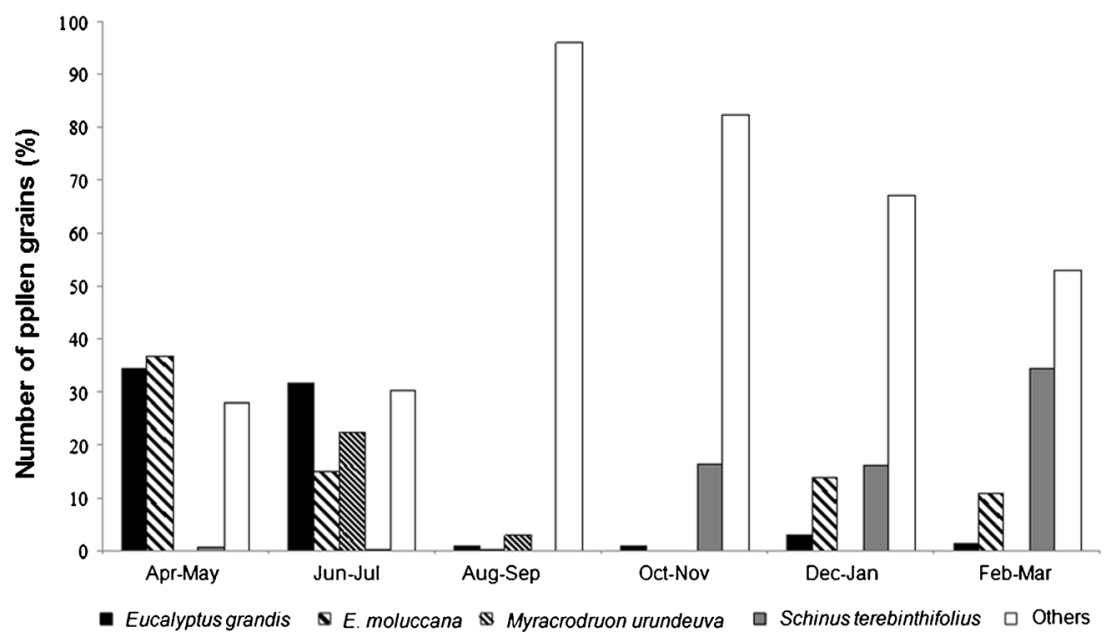

Figure 3. Number of pollen grains $(\%)$ of the four most intensively exploited plant species compared to other sources used for food storage. 
many more species are available to $S$. aff depilis than are commonly used.

The availability of floral resources in the study area was seasonal for the bees. The seasonality in pollen availability, with an average date in February, means that most of this resource was available for the bees during the rainy season. Nectar was also available continuously, but most individuals provided this resource in the beginning of the dry season. However, the low seasonality for nectar availability showed that a great number of individuals that provided nectar were distributed in other months of the year, exhibiting peaks in the dry (August and May) and even in the rainy season (January and March). Throughout the year, there was an increase in the availability of floral resources during the rainy season. Rainfall influenced the abundance of plant individuals that provided pollen in the study area, which is a characteristic of tropical environments where flowering, and consequently resource availability, is strongly associated with seasonal variations in rainfall (van Schaik et al. 1993).

As we hypothesized, food storage in EBs was greater during the rainy season. Besides being the season with higher resource availability, it was also characterized by higher ambient temperatures, providing bees with favorable conditions to fly, collect and store food resources. February-March was the month-pair with highest intensity of food storage by bees, and coincided with the peak period of pollen and nectar availability among sampled plant communities. Besides, it was also characterized by the highest ambient temperatures of the year. In stingless bees, pollen-foraging activity reflects the influence of climatic parameters, and ambient temperature is one of the most important abiotic factors for regulating the timing of food collection-daily onset and end (Hilário et al. 2001; Pick and Blochtein 2002; Leonhardt et al. 2014; Maia-Silva et al. 2014). Body size is another factor that influences the start of flight activity of stingless bees. Larger species, such as the genus Melipona, begin their activities in lower temperatures than smaller ones, such as the genus Scaptotrigona, which do not fly in temperatures under $15{ }^{\circ} \mathrm{C}$ (Teixeira and Campos 2005; Figueiredo-Mecca et al. 2013). Therefore, foraging activity during the colder dry season in S. depilis is restricted between $10 \mathrm{am}$ and $13 \mathrm{pm}$ in tropical areas (Figueiredo-Mecca et al. 2013). Low temperatures reduce metabolic rates, thereby impeding flight activity in small and medium-sized bees.

The storage of a larger quantity of pollen and nectar during the months with a high abundance of flowering plants is also common in other bee species. In colonies of Apis mellifera, variation in the intensity of pollen collection is strongly related to flowering seasonality (Keller et al. 2005). Stingless bees of the genus Melipona harvest pollen continuously, with a peak period during the increase in resource availability (Roubik 1982). The higher the pollen availability, the higher the number of foraging bees allocated to harvest pollen and nectar (Biesmeijer et al. 1999). Indeed, the number of $S$. aff. depilis workers that returns to the colonies with pollen loads is higher in the rainy season (Faria et al. 2012), with a peak in February (Figueiredo-Mecca et al. 2013).

The positive relationship between food stored in EBs and resource availability, with an increase in the amount of food stored for the season with higher food availability, indicates active collection intensification by foragers. We believe that intensifying food collection in the season with higher food availability is an optimization strategy of perennial and generalist colonies to meet their continuous demands for food in the tropics, thus preventing potentially fatal colony-weakening during periods of resource scarcity. During the colder dry season, foraging bees stored only pollen in food pots, i.e., the colonies only ensure the maintenance of protein reserves that are essential for the development of larvae. The absence of honey in EBs from April to July (Table I) indicates that colonies minimize any unnecessary costs related to nectar foraging when resource availability and ambient temperature are low, and maximize their nectar intake as soon as ambient temperature began to rise. The surplus of honey amassed in the rainy season would be enough to maintain the colonies in the subsequent months of the dry season.

Our study showed that foragers of $S$. aff. depilis used the same proportion of pollen types to store food, considering the plant species that bloomed in each season (18\% in each season). Here, the relevant observation is the amount of resources 
stored from those pollen types. The bees used pollen from a small number of sources, and their food pots were dominated by only eight tree and a liana species, showing that, even though foragers display a generalist habit, they are temporarily selective in their food choice, exploiting the most profitable ones as predicted by optimal foraging theory (MacArthur and Pianka 1966; Eltz et al. 2001). Other studies have also shown that stingless bees obtain most of their food from a small number of plant species (Imperatriz-Fonseca et al. 1988; Vossler et al. 2010; Aleixo et al. 2013; Leonhardt et al. 2014). The tree species E. moluccana, E. grandis, E. uniflora, M. caesalpiniifolia, M. urundeuva, and S. terebinthifolius were highly visited by $S$. aff. depilis because they produce small, inconspicuous, generalized flowers, clustered in dense inflorescences. The high concentration of resources in the crowns of those trees serves as a visual display for stingless bees, which amount to approximately $70 \%$ of all bees foraging in the canopy of Brazilian Tropical Atlantic Rainforest (Ramalho 2004). Odoux et al. (2012) also demonstrated the role of trees as major sources for honeybees in a cereal farming context.

In the present study, food availability for bees was continuous, which could explain the lack of correlation between available and used diversity. Pollen diversity found in food pots was highest in the dry season, when community-level source diversity was also highest in the study area, and the plant species were used more evenly in the dry season than in the rainy season. The dry season was when the arboreal stratum had species that flowered massively, such as E. moluccana, $E$. grandis, and $M$. urundeuva, which were intensively exploited by $S$. aff. depilis foragers. These species represented excellent sources to amass floral resources within the nests, contributing up to $45 \%$ to the nutritional input into the colonies during the dry season. Mass flowering plants produce a great number of flowers each day, thus providing large amounts of pollen and/or nectar to flower visitors (Gentry 1974) and appear among the sources most frequently used by bees of the genus Scaptotrigona (Ramalho 1990; Ferreira et al. 2010; Faria et al. 2012). Scaptotrigona species forage in groups (Jarau et al. 2003). As foraging bees recruit other bees from the nest, they can concentrate pollen harvesting from profitable sources, such as mass flowering tree species (Wilms et al. 1996; Ramalho 2004).

In the rainy season, the food pots were dominated by sources that were not intensively exploited-E. moluccana, E. uniflora, M. caesalpiniifolia, M. calabura, P. granatum, and $S$. lethalis - and this could explain the lower value of evenness in this season. These six plant species contributed up to $64 \%$ to the nutritional input into the colonies, which indicates that bees attempt to unevenly use the plant species for food storage in the rainy season. The collection of pollen from a variety of plant species could represent a strategy to ensure the larval food quality. For example, if generalist bees are exposed to a greater diversity of plant secondary compounds, mixing pollen from a variety of plant species could dilute the negative effects of any one compound and prevent larval toxicity (Irwin et al. 2014).

This study contributes to the understanding of how bee foraging behavior is shaped by the association between seasonal variation in resource availability and ambient temperature across a tropical landscape, which is critical for understanding bee-plant interactions. Data on the plant species that bees use as food sources provides a base for the elaboration of management plans and the conservation of both bee and plant species, which depend on the first for pollination. Besides that, the acquired knowledge in this study has applicability for commercial production of honey and pollen by stingless bee beekeepers and for colony management for pollination purposes.

\section{ACKNOWLEDGMENTS}

We thank FAPESP (2010/10285-4) and PNPD CAPES (02958/09-0) for financial support. CAPES also provided scholarship to KPA. Special thanks to Astrid M. P. Kleinert, Isabel Alves dos Santos and Letícia B. de Faria for their help in an early version of the manuscript. We also thank Alistair Campbell and Letícia V. Ribeiro for reviewing the language, and, finally, the two anonymous reviewers whose critical comments helped to improve the manuscript.

La disponibilité saisonnière des ressources florales et la température ambiante façonnent le comportement 
d'approvisionnement de l'abeille sans aiguillon (Scaptotrigona aff. depilis)

régime alimentaire / généraliste / abeille indigène / analyse pollinique / région tropicale

Die saisonale Verfügbarkeit an floralem Nahrungsangebot und die Umgebungstemperatur beeinflussen das Fouragierverhalten der Stachellosen Biene (Scaptotrigona aff. depilis )

\section{Diät / Generalist / native Bienen / Pollenanalyse / tropische Region}

\section{REFERENCES}

Aleixo, K.P., Faria, L.B., Garófalo, C.A., Imperatriz Fonseca, V.L., Silva, C.I. (2013) Pollen collected and foraging activities of Frieseomelitta varia (Lepeletier) (Hymenoptera: Apidae) in an urban landscape. Sociobiology 60, 266-276

Biesmeijer, J.C., Born, M., Lukács, S., Sommeijer, M.J. (1999) The response of the stingless bee Melipona beecheii to experimental pollen stress, worker loss and different levels of information input. J. Apic. Res. 38, 33-41

Camillo, E., Garofalo, C.A. (1989) Analysis of the niche of two sympatric species of Bombus (Hymenoptera, Apidae) in Southeastern Brazil. J. Trop. Ecol. 5, 81-92

Eltz, T., Brühl, C.A., van der Kaars, S., Chey, V.K., Linsenmair, K.E. (2001) Pollen foraging and resource partitioning of stingless bees in relation to flowering dynamics in a Southeast Asian tropical rainforest. Insectes Soc. 48, 273-279

Erdtman, G. (1960) The acetolized method. A revised description. Sven. Bot. Tidskr. 54, 561-564

Faria, L.B., Aleixo, K.P., Garófalo, C.A., ImperatrizFonseca, V.L., Silva, C.I. (2012) Foraging of Scaptotrigona aff. depilis (Hymenoptera, Apidae) in an urbanized area: seasonality in resource availability and visited plants. Psyche . doi:10.1155/2012/630628

Ferreira, M.G., Manente-Balestieri, F.C.D., Balestieri, J.B.P. (2010) Pólen coletado por Scaptotrigona depilis (Moure) (Hymenoptera, Meliponini), na região de Dourados, Mato Grosso do Sul. Brasil. Rev. Bras. Entomol. 54, 258-262

Figueiredo-Mecca, G., Bego, L., Nascimento, F.S. (2013) Foraging behaviour of Scaptotrigona depilis (Hymenoptera, Apidae, Meliponini) and its relationship with temporal and abiotic factors. Sociobiology 60, 277-282

Gentry, A. (1974) Flowering phenology and diversity in tropical Bignoniaceae. Biotropica 6, 64-68

Hammer, Ø., Harper, D.A.T., Ryan, P.D. (2001) PAST: paleontological statistics software package for education and data analysis. Palaeontol. Electron. 4, 0-9.
Available on: http://palaeo-electronica.org/2001_1/ past/issue1_01.htm

Hilário, S.D., Imperatriz-Fonseca, V.L., Kleinert, A.M.P. (2001) Responses to climatic factors by foragers of Plebeia pugnax Moure (in litt.) (Apidae, Meliponinae). Rev. Bras. Biol. 61, 191-196

Hutcheson, K. (1970) A test for comparing diversities based on the Shannon formula. J. Theor. Biol. 29, 151-154

Imperatriz-Fonseca, V. L., Kleinert-Giovannini, A., Ramalho, M. (1988). Pollen harvest by eusocial bees in a nonnatural community in Brazil. J. Trop. Ecol., 5, 239-242.

Irwin, R.E., Cook, D., Richardson, L.L., Manson, J.S., Gardner, D.R. (2014) Secondary compounds in floral rewards of toxic rangeland plants: impacts on pollinators. J. Agric. Food Chem. 62, 7335-7344

Jarau, S., Hrncir, M., Schmidt, V.M., Zucchi, R., Barth, F.G. (2003) Effectiveness of recruitment behaviour in stingless bees (Apidae, Meliponini). Insectes Soc. 50, 365-374

Kajobe, R., Echazarreta, C.M. (2005) Temporal resource partitioning and climatological influences on colony flight and foraging of stingless bees (Apidae; Meliponini) in Ugandan tropical forests. Afr. J. Ecol. 43, 267-275

Kaluza, B.F., Wallace, H., Heard, T.A., Klein, A.M., Leonhardt, S.D. (2016) Urban gardens promote bee foraging over natural habitats plantations. Ecol. Evol. 6, 1304-1316

Keller, I., Fluri, P., Imdorf, A. (2005) Pollen nutrition and colony development in honey bees: part II. Bee World 86, 27-34

Kovach Computing Services (2012) Oriana version 4.0 for windows. Anglesey

Leonhardt, S.D., Heard, T., Wallace, H.M. (2014) Differences in the resource intake of two sympatric Australian stingless bee species. Apidologie 45, 514-527

Louveaux, J., Maurizio, A., Vorwohl, G. (1978) Methods of melissopalynology. Bee World 59, 139-153

MacArthur, R.H., Pianka, E.R. (1966) On optimal use of a patchy environment. Am. Nat. 916, 604-609

Maia-Silva, C., Imperatriz-Fonseca, V.L., Silva, C.I., Hrncir, M. (2014) Environmental windows for foraging activity in stingless bees, Melipona subnitida Ducke and Melipona quadrifasciata Lepeletier (Hymenoptera: Apidae: Meliponini). Sociobiology 61, 378-385

Menezes, C., Vollet-Neto, A., Imperatriz-Fonseca, V.L. (2012) A method for harvesting unfermented pollen from stingless bees (Hymenoptera, Apidae, Meliponini). J. Apic. Res. 51 , 240-244

Michener, C.D. (2007) The bees of the word. The Johns Hopkins University Press, Baltimore

Montero, I., Tormo, R. (1990) Análisis polínico de mieles de cuatro zonas montañosas de Extremadura. Nac. Asoc. Palinologica Lengua Esp. 5, 71-78

Odoux, J.F., Feuillet, D., Aupinel, P., Loublier, Y., Tasei, J.N., Mateescu, C. (2012) Territorial biodiversity and consequences on physico-chemical characteristics of 
pollen collected by honey bee colonies. Apidologie 43, 561-575

Pais, M., Varanda, E.M. (2010) Arthropod recolonization in the restorarion of a semideciduous forest in southeastern Brazil. Neotrop. Entomol. 39, 198-206

Pick, R.A., Blochtein, B. (2002) Atividade de coleta e origem floral do pólen armazenado em colônias de Plebeia saiqui (Holmberg) (Hymenoptera, Apidae, Meliponinae) no sul do Brasil. Rev. Bras. Zool. 19, 289-300

Pielou, E.C. (1966). The measurement of diversity in different types of biological collections. J. Theor. Biol., $13,131-144$.

Pinheiro, J., Bates, D., DebRoy, S., Sarkar, D. (2015) nlme: linear and nonlinear mixed effects models. Available at: http://cran.r-project.org/web/packages/n?lme/ nlme.pdf

R Development Core Team (2011) R: a language and environment for statistical computing, version 2.13.1. R Foundation for Statistical Computing, Vienna

Ramalho, M. (1990) Foraging by stingless bees of the genus, Scaptotrigona (Apidae, Meliponinae). J. Apic. Res. 29, 61-67

Ramalho, M., Kleinert-Giovannini, A., ImperatrizFonseca, V. L. (1990). Important bee plants for stingless bees (Melipona and Trigona) and Africanized honeybees (Apis mellifera) in neo-tropical habitats: a review. Apidologie, 21, 469-488.

Ramalho, M. (2004) Stingless bees and mass flowering trees in the canopy of Atlantic Forest: a tight relationship. Acta Bot. Bras. 18, 37-47

Roubik, D.W. (1982) Seasonality in colony food storage, brood production and adult survivorship: studies of Melipona in tropical forest (Hymenoptera: Apidae). J. Kans. Entomol. Soc. 55, 789-800
Roubik, D.W. (1989) Ecology and natural history of tropical bees. Cambridge University Press, New York

Shannon, C.E., Weaver, W. (1949) The mathematical theory of communication. University Illinois Press, Urbana

Smith, A.R., Lopez Quintero, I.J., Moreno Patino, J.E., Roubik, D.W., Wcislo, W.T. (2012) Pollen use by Megalopta sweat bees in relation to resource availability in a tropical forest. Ecol. Entomol. 37, 309-317

Teixeira, L.V., Campos, F.N.M. (2005) Stingless bees (Hymenoptera, Apidae) flight activity beginning: body size and ambient temperature influence. Rev. Bras. Zool. 7, 195-202

van Schaik, C.P., Terborgh, J.W., Wright, S.J. (1993) The phenology of tropical forests: adaptive significance and consequences for primary consumers. Annu. Rev. Ecol. Syst. 24, 353-377

Vossler, F.G., Telleria, M.C., Cunningham, M. (2010) Floral resources foraged by Geotrigona argentina (Apidae, Meliponini) in the Argentine Dry Chaco forest. Grana 49, 142-153

Wilms, W., Imperatriz-Fonseca, V.L., Engels, W. (1996) Resource partitioning between highly eusocial bees and possible impact of the introduced Africanized honey bee on native stingless bees in the Brazilian Atlantic Rainforest. Stud. Neotrop. Fauna. E. 31, 137-151

Zar, J.H. (1999) Biostatistical Analysis. Prentice Hall International Editions, New Jersey

Zuur, A.F., Ieno, E.N., Walker, N.J., Saveliev, A.A., Smith, G.M. (2009) Mixed effects models and extensions in ecology with R. Springer, New York 